\title{
Edycje i edytorzy polskich podręczników historii doby zaborów. Stan badań i ich perspektywy
}

\section{Wstęp}

Podręczniki szkolne (bo do nich zawężono tematykę niniejszego opracowania ${ }^{1}$ ) zawsze były bardzo istotnym elementem nowożytnego systemu oświatowego, od chwili, kiedy na szerszą skalę weszły do praktyki procesu dydaktycznego, stając się aż po dzień dzisiejszy jego nieodłączną pomocą. Tak też było w złożonych dziejach polskiej oświaty, przeżywającej swoje wzloty i upadki nie tylko w kontekście jakości myśli oświatowej, lecz także w związku ze skomplikowanymi dziejami naszej państwowości. Problem ten jest szczególnie widoczny w perspektywie czasu, kiedy Rzeczpospolita pozostawała pod obcą dominacją, a zatem w okresie zaborów, gdy na zawartość podręczników miały wpływ obce interesy polityczne, narodowe i oświatowe ${ }^{2}$. Kwestią newralgiczną dla zachowania tożsamości narodowej (obok nauczania języka ojczystego) pozostawało nauczanie ojczystej historii, kształtującej - do dzisiaj zresztą - świadomość narodową młodzieży,

* Dr hab., prof. UWr, Uniwersytet Wrocławski, Instytut Informacji Naukowej i Bibliotekoznawstwa, Zakład Teorii i Historii Książki, 50-137 Wrocław, pl. Uniwersytecki 9/13.

1 Termin ten w przypadku XIX stulecia ma zresztą specjalne znaczenie. Niniejsze rozważania oparto na podręcznikach szkolnych posiadających wyraźne cechy druku na potrzeby zorganizowanej edukacji, pomijając zatem monografie historyczne, podręczniki akademickie, a także podręczniki służące wyłącznie samokształceniu. Ze względu jednak na specyfikę szkoły dziewiętnastowiecznej, często opierającej się na kształceniu domowym, do zbioru służącego jako podstawa rozważań włączono m.in. wypisy historyczne przeznaczone do użytku młodzieży szkolnej.

2 Obszarem zainteresowania autora niniejszego opracowania są tereny, na których występowały szkoły polskie i (lub) produkowano polskie podręczniki, a zakres chronologiczny pracy to lata 1795-1918, obejmujące czas od ostatecznego rozbioru kraju po odzyskanie niepodległości. Z tego względu lata 1917-1918, mimo coraz szybszego rozwoju szkolnictwa polskiego w tym czasie, włączono do okresu, kiedy szkoła polska znajdowała się pod obcą dominacją. 
stąd też świadomość znaczenia podręcznika do nauczania historii i jego roli w zachowaniu polskości w czasie ponad stu dwudziestu lat pozostawania kraju pod obcą dominacją.

\section{Historyczne uwarunkowania dziejów polskiej oświaty w czasach zaborów}

Nie ulega wątpliwości, że rozwój nowoczesnego podręcznika w polskiej szkole - przy całym szacunku dla dokonań pierwszych siedmiu dekad XVIII wieku, związanych z działalnością zakonów nauczających - wiązać należy z działalnością Komisji Edukacji Narodowej i jej wyspecjalizowanej agendy - Towarzystwa do Ksiąg Elementarnych. To te instytucje zapoczątkowały formowanie się na wielką skalę zarówno myśli autorskiej, jeśli chodzi o przygotowanie podręczników do poszczególnych przedmiotów, jak również zasad korzystania z tej literatury zarówno przez nauczyciela, jak i ucznia. Osobną i jak dotąd najmniej zbadaną kwestią jest problematyka edycji wydań podręczników, a zatem zagadnień związanych z miejscem podręcznika w działalności oficyn wydawniczych i zakładów drukarskich.

Warto przy tym zauważyć, że na losy polskich podręczników - zwłaszcza zaś podręczników języka polskiego oraz historii - ogromny wpływ miał sposób traktowania inkorporowanych ziem polskich przez poszczególnych zaborców (trudno zatem mówić o możliwościach prowadzenia jednolitej polityki wydawniczej w tym względzie), jak też przypomnieć należy zmienną w swej represyjności politykę oświatową poszczególnych państw zaborczych wobec szkoły na terenach dawnej Rzeczypospolitej, co oznaczało nasilające się szykany lub przemyślane (ewentualnie wymuszone) ustępstwa na rzecz polskiej mniejszości etnicznej. Różnice widoczne w polityce poszczególnych państw zaborczych oraz ich władców w znaczący sposób odbiły się też na możliwościach edycji polskich podręczników do nauczania historii, czego dobrym przykładem jest względna swoboda publikacji tego typu materiałów w Królestwie Polskim za panowania Aleksandra I czy podobna sytuacja w Galicji, jednak dopiero pod rządami Franciszka Józefa I. Wszystkie te czynniki powodują, że trudno mówić o uniwersalności działań autorskich i wydawniczych, choć nie można nie zauważyć obecności polskiego podręcznika do nauczania historii na terenach zaborów innych aniżeli miejsce jego wydania. To zasługa działalności (zwłaszcza na przełomie XIX i XX wieku) polskich instytucji wydawniczych ponad granicami zaborów, lecz także problem recepcji tego gatunku książki, niewchodzący w zakres niniejszego opracowania.

\section{Losy polskich podręczników historii tego czasu}

Podstawą wszelkich działań badawczych w kwestii dziejów podręczników do nauczania historii (podobnie jak i podręczników do innych przedmiotów) jest opracowanie możliwie pełnej bibliografii tychże pomocy naukowych. Bibliografia 
taka do chwili obecnej nie została przygotowana - przynajmniej w odniesieniu do wieku XIX - choć położone zostały pod nią podwaliny w postaci trzystu opisów bibliograficznych, zawartych w pracy Marii Bieniek Obudowa dydaktyczna polskich podręczników historii 1795-1914³. To najnowszy i najpełniejszy spis polskich podręczników historii ${ }^{4}$, co istotne - obejmujący wszystkie części podzielonego kraju. Wcześniej w pewnym stopniu lukę tę wypełniały bibliografie (także załącznikowe), ukazujące fragmenty zasobów podręcznikowych, w tym także historycznych. Przykładem są źródła bibliograficzne autorstwa Aleksandra Rombowskiego - przedstawiające polskie podręczniki w zbiorach dawnych bibliotek Wrocławia ${ }^{5}$, Stefana Możdżenia - przynoszące informacje o podręcznikach stosowanych w szkołach galicyjskich doby autonomii ${ }^{6}$ czy też Józefa Wojtala - omawiające podręcznikowe dokonania oficyny ossolińskiej ${ }^{7}$. Warto też może wspomnieć o pracy Mieczysława Grzyba, przynoszącej informacje bibliograficzne m.in. na temat podręczników epoki Komisji Edukacji Narodowej ${ }^{8}$ (jak wiadomo bardzo znaczącej dla pierwszych dziesiątków lat XIX wieku), a także o katalogu podręczników zalecanych w polskich już szkołach powszechnych w 1920 r. ${ }^{9}$, zawierającym jednak także dawniejsze edycje.

Oczywiście opisy wielu podręczników szkolnych znajdziemy także w podstawowych źródłach bibliograficznych, a zatem w Bibliografii polskiej XIX wieku Karola Estreichera czy Bibliografii polskiej 1901-1939, źródła te jednak (zwłaszcza w ich tradycyjnej formie) są niełatwe w korzystaniu ze względu na swój specyficzny układ i brak stosownych indeksów, które umożliwiałyby poszukiwania według haseł przedmiotowych. Innym źródłem informacji pośredniej są zachowane katalogi

3 M. Bieniek, Obudowa dydaktyczna polskich podręczników historii 1795-1914, Olsztyn 2001. Praca ta zawiera: na s. 272-275 - podręczniki wydane w latach 1795-1830, poz. 20; s. 276-281 - podręczniki doby międzypowstaniowej (1831-1863), ok. 40 poz.; s. 282-285 - podręczniki wydane i używane w Królestwie Polskim w latach 1864-1914, średni poziom szkolnictwa, ok. 30 poz.; s. 286-291 - podręczniki wydane i używane w Galicji w latach 1866-1914, średni poziom kształcenia, ok. 40 poz.; s. 292-295 - podręczniki wydane w zaborze pruskim w latach 1864-1914, poz. 14; s. 296-299 - podręczniki elementarne wydane w Królestwie Polskim w latach 1864-1914, poz. 31; s. 300-301 - podręczniki elementarne wydane w Galicji w latach 1866-1914, poz. 18, a także na s. 305-333 - piśmiennictwo polskie i zagraniczne, ok. 650 poz.

${ }_{4}^{4}$ Autorka szeroko potraktowała formułę podręcznika, włączając do zestawienia bibliograficznego także monografie, popularne kompendia wiedzy historycznej, a także podręczniki służące autoedukacji. Wbrew intencji jej książki, w zestawieniu tym znalazły się też podręczniki używane na ziemiach polskich pod zaborami, wydane jednak jako prace obcych autorów, w obcych językach i drukowane poza terenem dawnej Rzeczypospolitej. Por. taż, Obudowa dydaktyczna..., s. 305-317.

5 A. Rombowski, Polskie podręczniki w dawnych księgozbiorach wrocławskich, „Sobótka” 1960, R. 15, nr 1, s. 23-36.

6 S. I. Możdżeń, Podręczniki w galicyjskich szkołach średnich (1860-1885). „Acta Universitatis Wratislaviensis” 1975, Prace Pedagogiczne, T. 7, s. 51-59. Tu także bibliografia podręczników używanych w szkołach średnich Galicji w latach 1860-1885 (w układzie według przedmiotów nauczania).

7 J. Wojtal, Ossolińskie podręczniki i książki szkolne z lat 1878-1918. Materiały bibliograficzne, „Rocznik Zakładu Narodowego im. Ossolińskich” 1972, T. 7, s. 119-134.

8 M. Grzyb, Przegląd podręczników i innych prac do nauczania historii w Polsce przed reformą Komisji Edukacji Narodowej i w czasie jej działalności, „Śląskie Studia Historyczne” 1977, T. 2, s. $205-218$.

9 Spis podręczników szkolnych dla szkół powszechnych siedmioklasowych na rok szkolny 1920/21, Warszawa 1920, s. 15. 
wydawnicze i księgarskie, polecające ten rodzaj wydawnictw, a także inseraty i ogłoszenia, pełniące identyczną rolę na łamach czasopism.

W tej sytuacji kluczowym problemem staje się przygotowanie możliwie pełnej bibliografii podręczników szkolnych do nauczania historii, wydanych w czasach zaborów, którego to zadania podjął się autor niniejszego opracowania.

Podstawowym źródłem informacji, obok omawianych bibliografii, katalogów księgarskich i wydawniczych, a także ogłoszeń prasowych, stały się w tym przypadku katalogi biblioteczne, zwłaszcza zaś katalog podręczników szkolnych stanowiących własność Biblioteki Narodowej w Warszawie, która to biblioteka posiada obszerny, choć daleki od kompletności zbiór tego gatunku książek. Lista odnalezionych w zbiorach BN podręczników do nauczania historii została uzupełniona poprzez egzemplarze przechowywane w innych wielkich bibliotekach naukowych, a mianowicie w Bibliotece Jagiellońskiej, Bibliotece Uniwersytetu Warszawskiego, Bibliotece Uniwersytetu im. Adama Mickiewicza w Poznaniu, Bibliotece Uniwersytetu Mikołaja Kopernika w Toruniu i tamtejszej Książnicy Kopernikańskiej, Bibliotece Zakładu Narodowego im. Ossolińskich we Wrocławiu, Bibliotece Śląskiej, Miejskiej Bibliotece Publicznej im. Józefa Piłsudskiego w Łodzi, Bibliotece Poznańskiego Towarzystwa Przyjaciół Nauk i kilku innych księgozbiorach, zawierających znaczne zasoby XIX-wiecznych poloniców. Dodać wypada, że ciekawe edycje poszukiwanej literatury zachowały się też w kilku większych bibliotekach pedagogicznych i stanowią w niektórych przypadkach jedyne istniejące egzemplarze ${ }^{10}$. Dowodzi to ogromnego rozproszenia tego gatunku edycji, a także niekompletności zasobów bibliotecznych, co wynika z użytkowej wartości podręcznika, a w następstwie tego z niskiej oceny wartości owej literatury przez bibliotekarzy. Zniszczone, zaczytane egzemplarze dawnych podręczników szkolnych rzadko były włączane do księgozbiorów naukowych, czego efekty obserwujemy w księgozbiorach bibliotek współczesnych, w których próżno szukać wielu nie tylko wydań, lecz nawet tytułów ${ }^{11}$.

W każdym razie utworzenie możliwie pełnego spisu polskich podręczników okresu zaborów stanowi warunek podjęcia poważnych badań naukowych zarówno nad ich treściami, jak i dziejami edycji. Do chwili obecnej autorowi niniejszego opracowania udało się zidentyfikować blisko 230 edycji (nie licząc wznowień) polskich podręczników szkolnych do nauczania historii wydanych w latach 17951918, lecz ich lista pozostaje jeszcze niepełna ${ }^{12}$.

10 Mowa tu m.in. o Pedagogicznej Bibliotece Wojewódzkiej im. Prof. Tadeusza Kotarbińskiego w Łodzi, Publicznej Bibliotece Pedagogicznej w Poznaniu oraz Książnicy Pedagogicznej im. Alfonsa Parczewskiego w Kaliszu. Zbiory dawnych podręczników szkolnych tej ostatniej placówki prezentowane są w pracy Dawne polskie podręczniki szkolne w zbiorach Książnicy Pedagogicznej im. Alfonsa Parczewskiego w Kaliszu. Katalog, Kalisz 2010.

11 Dzisiaj dawny podręcznik szkolny stał się wartościowym nabytkiem, poszukiwanym przez wiele bibliotek. Stosunkowo najbogatsze zbiory posiadają Biblioteka Narodowa w Warszawie oraz Biblioteka Jagiellońska w Krakowie, w części uzupełniane przez inne księgozbiory biblioteczne, wiele jednak edycji znamy już tylko z opisu bibliograficznego.

12 Jeśli chodzi o miejsca ich wydania, to dominuje na tej liście Warszawa (67 edycji), następnie Lwów (31), Kraków (28), Poznań (15), Wilno (14), Wrocław i Gniezno (po 8), Lublin (5), Chicago i Toledo (Ohio) (po 4), Jazłowiec, Leszno, Rzeszów, Stanisławów i Wiedeń (po 3). Po dwie edycje 


\title{
Dokonania historiografii w zakresie informacji o podręcznikach historii oraz ich treści
}

\author{
Tło historyczne i dzieje oświaty
}

Polska szkoła w czasy drugiego i trzeciego rozbioru kraju weszła z podręcznikami do nauczania historii przygotowanymi jeszcze przez Towarzystwo do Ksiąg Elementarnych Komisji Edukacji Narodowej, którego dokonania jeszcze długo służyły edukacji szkolnej, tworząc nową wartość dydaktyczną i edytorską formowanej w tym czasie podstawowej pomocy szkolnej, jaką stawał się w drugiej połowie XVIII wieku podręcznik szkolny.

Literatura w tej mierze jest bardzo obszerna i dotyczy zarówno dziejów powstania, działalności i likwidacji Komisji Edukacji Narodowej ${ }^{13}$, jak też i działalności wspomnianego wyżej Towarzystwa. Szczególne nasilenie publikacji tym problemom poświęconym przypada na obchody dwustulecia powstania KEN, choć nie można - oceniając ich wartość - zapomnieć, że w wielu przypadkach ocena wartości działań Komisji budowana była w opozycji do sprawiedliwego osądu działalności szkolnictwa jezuickiego w ostatnich dziesięcioleciach jego istnienia, a także pracy oświatowej zakonu pijarów.

$\mathrm{Na}$ osobną wzmiankę zasługuje obszerna literatura omawiająca losy polskiej oświaty w XIX wieku, stanowiąca szerokie tło problematyki edycji podręcznikowych. Tu wymienić należy zarówno opracowania ukazujące warunki działania szkoły na ziemiach polskich (w tym cenne prace Jerzego Maternickiego, Czesława Majorka, Wita Górczyńskiego, Tadeusza Słowikowskiego, Wandy Zwolskiej,

opuściły Chełmno, Kołomyję, Krzemieniec, Łódź, Moskwę, Petersburg, Tarnopol oraz Złoczów, zaś po jednej wydano w Berdyczowie, Charkowie, Inowrocławiu, Jarosławiu, Jędrzejowie, Krotoszynie, Marywilu, Mikołowie, Nowym Sączu, Ostrowie Wielkopolskim, Paryżu, Pelplinie, Połocku, Przemyślu, Trzemesznie i Żytomierzu.

${ }_{13}$ Pośród setek publikacji na temat Komisji Edukacji Narodowej wymienić trzeba najistotniejsze z nich, a zatem źródła do dziejów KEN (m.in. w postaci wydanych drukiem materiałów wizytacji szkół), a także najbardziej wartościowe z opracowań poświęconych nauczaniu historii, za które uznać należy m.in. prace: M. Grzyb, Stan nauczania historii w dobie Komisji Edukacji Narodowej, „Zeszyty Naukowe WSP w Katowicach" 1964, Nr 22, Prace Historyczne, nr 1, s. 45-66; M. R. Lang, Geneza Towarzystwa do Ksiąg Elementarnych, „Przegląd Humanistyczny” 1976, R. 20, nr 10, s. 15-28; C. Majorek, Nauczanie historii Polski w szkołach średnich Komisji Edukacji Narodowej, „Przegląd Humanistyczny” 1977, R. 21, nr 5, s. 21-36; tenże, Podręczniki Komisji Edukacji Narodowej w aspekcie rozwiązań dydaktycznych, „Rozprawy z Dziejów Oświaty” 1973, T. 16, s. 69-140; C. Majorek, T. Słowikowski, Historia ojczysta w szkołach Komisji Edukacji Narodowej, „Wiadomości Historyczne” 1973, R. 16, nr 3, s. 105-114; J. Maternicki, Teoria i praktyka nauczania historii w dobie Komisji Edukacji Narodowej, „Przegląd Humanistyczny” 1973, R. 17, nr 4, s. 61-79; Reforma Programu Szkolnego Komisji Edukacji Narodowej, wybór tekstów J. Lubieniecka, Warszawa 1962; T. Słowikowski, Komisja Edukacji Narodowej wobec nauczania historii, „Rocznik Naukowo-Dydaktyczny WSP w Krakowie” 1974, Z. 52, Prace Historyczne, nr 7, s. 7-23; A. Sobczak, Nauczanie historii w szkołach Komisji Edukacji Narodowej, „Rozprawy z Dziejów Oświaty” 1973, T. 16, s. 141-194; S. Truchim, Wzajemne stosunki Pijarów i Komisji Edukacji Narodowej. (Autoreferat z pracy spalonej w czasie Powstania Warszawskiego), „Sprawozdania Łódzkiego Towarzystwa Naukowego” 1947, R. 2, nr 1, s. 63-65. 
a także wielu innych autorów ${ }^{14}$ ), jak też biograficzne kompendia i opracowania, przypominające środowiska i poszczególnych ludzi - historyków i nauczycieli, stanowiących niezwykle istotny element procesu edukacji, w każdym zresztą czasie $^{15}$. Ta ogromna ilość literatury, pochodzącej notabene z różnych lat i okre-

${ }_{14}$ W tym miejscu trzeba przytoczyć m.in. prace: J. Dybiec, Mecenat naukowy i oświatowy w Galicji 1860-1918, Wrocław 1981; Edukacja historyczna społeczeństwa polskiego w XIX w., red. J. Maternicki, Warszawa 1981; W. Górczyński, Historia, polityka, wychowanie. Nauczanie dziejów ojczystych w szkołach średnich Królestwa Polskiego 1815-1872, Warszawa 1988; tenże, Losy edukacji historycznej w szkołach średnich Królestwa Polskiego w latach 1864-1872, [w:] Historia. Poznanie i przekaz, red. B. Jakubowska, Rzeszów 2000; tenże, Repolonizacja edukacji historycznej w dobie reformy oświatowej Aleksandra Wielopolskiego, „Wiadomości Historyczne” 1982, R. 25, nr 5, s. 413-438; J. Maternicki, C. Majorek, W. Górczyński, Historia jako zadanie wychowawcze. Edukacja historyczna młodzieży w latach 1773-1830, Warszawa 1988; H. Kasperowiczowa, Szkolnictwo polskie w Petersburgu w latach pierwszej wojny światowej. Wspomnienia, „Przegląd Historyczno-Oświatowy” 1961, R. 4, nr 1, s. 79-90. K. Kawecka, Z dziejów szkolnictwa polskiego w Związku Radzieckim 1917-1923, „Z Dziejów Stosunków Polsko-Radzieckich” 1970, T. 7, s. 139-155; H. Konopka, Edukacja historyczna w szkołach elementarnych Królestwa Polskiego w latach 1905-1907, „Przegląd Humanistyczny” 1982, R. 26, nr 1-2, s. 237-248; C. Majorek, Historia utylitarna i erudycyjna. Szkolna edukacja historyczna w Galicji (1772-1918), Warszawa 1990; tenże, Popularyzacja historii Polski wśród ludu w Galicji doby autonomicznej (1867-1914), „Sprawozdania z Posiedzeń Komitetu Naukowego PAN. Oddział w Krakowie" 1979, T. 23, cz. 1 [druk. 1981], s. 51-53; J. Maternicki, Dydaktyka historii w Polsce. 1773-1918, Warszawa 1974; tenże, Idee i postawy. Historia i historycy polscy 1914-1918. Studium historiograficzne, Warszawa 1975; tenże, Nauczanie historii w szkołach średnich Księstwa Warszawskiego i Królestwa Polskiego (do 1830 r.), „Rozprawy z Dziejów Oświaty” 1974, T. 17, s. 51-103; tenże, Problemy metodologiczne badań nad dziejami dydaktyki historii, [w:] Edukacja historyczna a współczesność, red. B. Kubis, Opole 2002, s. 165-178; J. Maternicki, C. Majorek, A. Suchoński, Dydaktyka historii, wyd. 2, Warszawa 1994; K. Mrozowska, Tradycje Komisji Edukacji Narodowej w szkolnictwie polskim XIX wieku, „Przegląd Historyczno-Oświatowy” 1972, R. 15, nr 3, s. 403-424; E. Podgórska, Szkolnictwo elementarne Księstwa Warszawskiego i Królestwa Kongresowego 1807-1831, Warszawa 1960, ss. 192; Polska XIX wieku. Państwo, społeczeństwo, kultura, red. J. Tazbir, wyd. 3. Warszawa 1977, ss. 367; K. Poznański, Oświata i szkolnictwo w Królestwie Polskim 1831-1869. Lata zmagań i nadziei, T. 2: Szkoły rzemieślniczo-niedzielne, Warszawa 2001; T. Słowikowski, Echa Komisji Edukacji Narodowej w nauczaniu historii na ziemiach polskich w pierwszych dziesiątkach lat XIX wieku, „Sprawozdania z Posiedzeń Komitetu Naukowego PAN Oddział w Krakowie” 1973, T. 17, Cz. 1; T. Słowikowski, Problematyka dziejów dydaktyki historii - stan badań i perspektywy, Kraków 1985, [w:] Dydaktyka historii na kierunkach nauczycielskich w uniwersytetach i wyższych szkołach pedagogicznych. Materiały z ogólnopolskiej konferencji naukowej (Kraków, 5-6 grudnia 1979 r.), red. A. Kulczycka-Ślusarczyk, J. Ruchała, s. 38-55; S. Truchim, Współpraca polsko-rosyjska nad organizacją szkolnictwa rosyjskiego w początkach XIX wieku, Łódź 1960; W. Zwolska, Programy nauczania historii w gimnazjach galicyjskich w latach 1867-1914, „Zeszyty Naukowe Uniwersytetu Łódzkiego” 1971, Ser. 1. Nauki Humanistyczno-Społeczne, z. 76: Historia XIX i XX w., s. 85-104; W. Zwolska, Rola historii i metody jej nauczania w gimnazjach galicyjskich w latach 1867-1914, „Przegląd Historyczno-Oświatowy” 1970, R. 13, nr 4, s. 532-550; W. Zwolska, Sprawa nauczania historii kraju rodzinnego w gimnazjach galicyjskich w latach 1867-1914, „Małopolskie Studia Historyczne” 1966, R. 9, z. 1-2, s. 25-45.

15 Historycy warszawscy ostatnich dwóch stuleci, red. A. Gieysztor, J. Maternicki, H. Samsonowicz, Warszawa 1986; R. IInicka-Miduchowa, Nauczyciele historii w szkołach średnich w dobie Komisji Edukacji Narodowej, „Roczniki Naukowo-Dydaktyczne WSP w Krakowie” 1974, Z. 52, Prace Historyczne, nr 7, s. 24-48; J. Maternicki, Polskie szkoły historyczne we Lwowie w XIX w., [w:] Wielokulturowe środowisko historyczne Lwowa w XIX i XX w., T. 3, Rzeszów 2005, s. 23-45; tenże, Warszawskie środowisko historyczne. 1832-1869, Warszawa 1970; tenże, Warszawskie środowisko historyków wobec rewolucji w Rosji i perspektyw niepodległości w okresie I wojny światowej, „Wiadomości Historyczne" 1981, R. 24, nr 6 [druk. 1982], s. 349-357; tenże, Warszawskie środowisko historyczne 
sów polskiej historiografii, przynosi informację dość zróżnicowaną, często jednak zaskakującą swoją zawartością. Warto tu przypomnieć, iż wątek biograficzny polskiej książki pedagogicznej w ogólności nie był, jak dotąd, przesadnie eksponowany, zatem warto wzbogacić rozważania poświęcone podręcznikom szkolnym o przypomnienie postaci ich autorów ${ }^{16}$.

\section{Prace poświęcone podręcznikom i ich treści}

Istnieje też wiele prac poświęconych podręcznikom historii w rozmaitych aspektach ich funkcjonowania. I tak z perspektywy historycznej warto wyróżnić opracowania tyczące się podręczników jezuickich i pijarskich, stanowiących prehistorię gatunku ${ }^{17}$, następnie zaś podręczniki Komisji Edukacji Narodowej, jak wspomniano wcześniej, w wielu przypadkach używane, a nawet wznawiane nie tylko w końcu XVIII, ale i w początkach XIX wieku'18. Obszerną literaturę posiada podręcznik dziewiętnastowieczny, jeśli chodzi o ogólne aspekty jego funkcjonowania w rzeczywistości szkolnej. Najistotniejszymi przykładami w tej mierze są prace Marii Bieniek ${ }^{19}$, poświęcone m.in. obudowie podręcznika ${ }^{20}$, a także opracowania

w okresie rewolucji 1905 i wzrostu dążeń niepodległościowych przed I wojną światową, „Przegląd Humanistyczny" 1980, R. 24, nr 6, s. 1-30; 1981, R. 25, nr 1-2, s. 113-138; A. Puszka, Wykształcenie nauczycieli historii państwowych szkół średnich w Galicji w okresie autonomii, [w:] Nauczyciel historii. Ku nowej formacji dydaktycznej, red. M. Kujawska, Poznań 1996, s. 16-22; W. Zwolska, Nauczyciele historii w gimnazjach galicyjskich w dobie autonomicznej (1867-1914 r.), „Rocznik Łódzki” 1971, T. 15, s. 183-199.

${ }_{16}$ Pewne informacje na temat autorów poszczególnych podręczników szkolnych do nauki historii znaleźć możemy w kompendiach biograficznych poświęconych środowiskom historyków, znane są także biografie poświęcone najwybitniejszym historykom, będącym czasami także autorami podręczników. Stosunkowo rzadko natomiast można się natknąć na prace dedykowane mniej znanym, czy zapoznanym autorom. Jednym z nielicznych tego przykładów może być artykuł B. Nawroczyńskiego, Cecylia Niewiadomska - tajna nauczycielka (1855-1925), „Przegląd Historyczno-Oświatowy” 1978, R. 21, nr 4, s. 505-507.

17 A. Krawczyk, „Historia Polski” Pierre’a Solignaca - nieznany podręcznik szkół pijarskich, [w:] Historia. Poznanie i przekaz, red. B. Jakubowska, Rzeszów 2000; T. Słowikowski, Pijarskie podręczniki do nauczania historii w Polsce w XVIII wieku, „Nasza Przeszłość” 1980, T. 54, s. 181-229; A. Wojtkowski, Walka z tyranią, podbojami i krzywdą społeczną w pijarskich podręcznikach historii, „Roczniki Humanistyczne” 1977, T. 25, z. 2 [druk 1978], s. 107-126.

18 R. Ilnicka-Miduchowa, Podręczniki do nauczania historii w dobie Komisji Edukacji Narodowej, „Roczniki Naukowo-Dydaktyczne WSP w Krakowie” 1972, Z. 43, Prace Historyczne, nr 6, s. 53-76; C. Majorek, Książki szkolne Komisji Edukacji Narodowej, Warszawa 1975; tenże, Podręcznik Komisji Edukacji Narodowej w praktyce nauczania szkół średnich (1778-1794), [w:] Nowożytna myśl naukowa w szkołach Komisji Edukacji Narodowej, red. I. Stasiewicz-Jasiukowa, Wrocław 1973; tenże, Zarys teorii podręcznika szkolnego Komisji Edukacji Narodowej, [w:] Na przełomie wieków. Studia z dziejów Komisji Edukacji Narodowej, red. nauk. Kamilla Mrozowska, „Studia Pedagogiczne” 1973, T. 29, Wrocław; T. Słowikowski, R. IInicka-Miduchowa, Sprawa wojen i pokoju powszechnego w polskich podręcznikach do nauczania historii w dobie Komisji Edukacji Narodowej, „Przegląd Historyczno-Oświatowy" 1972, R. 15, $\mathrm{nr} 3$, s. 528-540.

19 M. Bieniek, Obudowa dydaktyczna...

20 Według Encyklopedii pedagogicznej XXI wieku (T. 4, Warszawa 2005, s. 461-470) termin ten oznacza podręcznik wzbogacony o materiały uzupełniające, ułatwiające nabycie wiedzy oraz jej 
autorstwa m.in. Jerzego Maternickiego oraz Wandy Zwolskiej, poświęcone rozmaitym aspektom podręcznika jako gatunku pisarskiego i elementu dydaktyki ${ }^{21}$. $\mathrm{Na}$ osobne potraktowanie zasługuje problematyka zawartości podręczników do nauczania historii, zarówno z punktu widzenia zawartości merytorycznej, jak i działań metodycznych ${ }^{22}$. Tu zauważyć możemy szczególnie szerokie spektrum zainteresowań - od problematyki społecznej, religijnej i narodowej (chłopi, kobiety, arianie, Żydzi w podręcznikach szkolnych) po zagadnienia epok i wydarzeń historycznych (m.in. Krzyżacy, bitwa pod Grunwaldem i in.).

przyswojenie. Są to w przypadku podręcznika do nauki historii m.in. zeszyty ćwiczeń, wypisy literackie, atlasy oraz rozmaitego rodzaju materiały multimedialne.

${ }^{21}$ R. Cybulski, Podręczniki szkolne w wileńskim okręgu naukowym w latach 1803-1831, „Rocznik Biblioteki Narodowej” 1974, T. 10 [druk 1975], s. 181-201; K. Gawroński, Wpływ krakowskiej szkoły historycznej na galicyjskie podręczniki historii Polski doby pozytywizmu, „Przegląd Humanistyczny” 1981, R. 25, nr 6 [druk 1982], s. 131-147; A. Glimos-Nadgórska, Rola i funkcja podręcznika jako podstawowego źródła dydaktycznego (na przykładzie podręcznika historii), „Wiadomości Historyczne” 1980, R. 23, nr 2, s. 76-82; A. Ładyżyński, Podręczniki w szkołach zawodowych Galicji doby autonomicznej, [w:] Studia z dziejów oświaty i myśli pedagogicznej XVII-XX wieku, red. S. Walasek, Wrocław 1996, s. 39-53; W. Martynowiczówna, Podręcznik w nauczaniu historii w szkole powszechnej, „Praca Szkolna” 1946/1947, R. 19, s. 102-110; J. Maternicki, Trzy typy szkolnego podręcznika historii, „Wiadomości Historyczne" 1975, R. 17 [właśc.18], nr 4, s. 162-169; Z. Michalik, Na drodze ku integralnej wizji dziejów Polski. Podręczniki szkolne przełomu XIX i XX wieku, „Przegląd Humanistyczny” 1981, R. 25, nr 1-2, s. 233-245; S. I. Możdżeń, Podręczniki w galicyjskich szkołach średnich (1860-1885), „Acta Universitatis Wratislaviensis” 1975, Prace Pedagogiczne”, T. 7; J. Rell, Problematyka kultury w dawnych podręcznikach historii Polski (1795-1830), „Przegląd Humanistyczny” 1978, R. 22, nr 1, s. 43-57; J. Semków, Reforma podręczników dla szkół ludowych pospolitych w opinii społeczeństwa polskiego Galicji (1893-1901), „Prace Humanistyczne Rzeszowskiego Towarzystwa Przyjaciół Nauk” 1975, Ser. 1. Wydział Nauk Humanistycznych, R. 4, nr 5, s. 19-37; M. Stinia, Podręczniki w gimnazjach galicyjskich w latach 1860-1918, „Prace Komisji Historii Nauki PAU” 2004, T. 6, s. 5-44; H. Szebesta, Pierwsze polskie podręczniki na Śląsku Cieszyńskim do połowy XIX wieku, „Przegląd Historyczno-Oświatowy" 1980, R. 23, nr 3, s. 361-370; M. Treszel, O podręcznikach szkolnych na Górnym Śląsku w czasach Józefa Lompy, „Kwartalnik Nauczyciela Opolskiego” 1973, R. 15, nr 2/3, s. 20-29; A. Wasiak, Wartości w minionych programach i podręcznikach, [w:] Wartości w edukacji historycznej, red. J. Rulka, Bydgoszcz 1999, s. 190-193; W. Zwolska, Podręczniki historii w gimnazjach galicyjskich w latach 1867-1914, „Zeszyty Naukowe Uniwersytetu Łódzkiego” 1972, Ser. 1. Nauki Humanistyczno-Społeczne, Z. 86: Historia XIX i XX w., s. 27-45; taż, Polskie podręczniki historii w gimnazjach galicyjskich doby autonomicznej, „Zeszyty Naukowe Uniwersytetu Łódzkiego” 1973, Ser. 1. Nauki Humanistyczno-Społeczne, Z. 96: Historia Polski XIX i XX w., s. 17-35.

22 J. Brynkus, Bohaterowie dziejów polskich w podręcznikach szkolnych XIX wieku, Kraków 1998; E. Cesarz, Chłopi w polskiej myśli historycznej doby porozbiorowej 1795-1864. Syntezy, parasyntezy i podręczniki dziejów ojczystych, Rzeszów 1999; W. Górczyński, Problematyka stosunków polsko-niemieckich i polsko-krzyżackich w szkolnych podręcznikach historii okresu międzypowstaniowego (1831-1863), [w:] Tradycja grunwaldzka, red. J. Maternicki, Cz. 2, Warszawa 1990; M. Hoszowska, Arianie i problem polskiej tolerancji religijnej w podręcznikach historii późnego Oświecenia, [w:] Wielokulturowe środowisko historyczne Lwowa w XIX i XX w., T. 5, Rzeszów 2007, s. 107-129; taż, Wizerunek kobiety w Iwowskich podręcznikach historii Polski XIX wieku, [w:] Wielokulturowe środowisko historyczne Lwowa w XIX i XX w., T. 3, Rzeszów 2005, s. 153-172; H. Konopka, Problematyka grunwaldzka w podręcznikach historii Polski wydanych w Królestwie Polskim w latach 1880-1905, [w:] Tradycja grunwaldzka, red. J. Maternicki, Cz. 2, Warszawa 1990; J. Pisulińska, Społeczność żydowska w galicyjskich podręcznikach dziejów Polski okresu popowstaniowego, [w:] Historia. Społeczeństwo. Wychowanie, red. J. Maternicki, M. Hoszowska, P. Sierżęga, Rzeszów 2003, s. 150-165; J. Pisulińska, Żydzi w polskiej myśli historycznej doby porozbiorowej (1795-1914). Syntezy, parasyntezy i podręczniki dziejów ojczystych, Rzeszów 2004. 
Pewna grupa opracowań dotyczy wkładu autorskiego, a także stosunku (zwykle krytycznego) do podręczników historii. Na czoło tej grupy publikacji wysuwają się prace poświęcone Lelewelowi jako autorowi i krytykowi podręczników, choć nie brak i innych wybitnych historyków oraz działaczy oświatowych ${ }^{23}$. Prawdziwym ewenementem są natomiast informacje przybliżające problem recepcji podręczników w środowisku oświatowym i czytelniczym ${ }^{24}$. To kolejny dowód, że podręcznik szkolny traktowany był niemal wyłącznie jako doraźna pomoc naukowa, o której losach najdobitniej dzisiaj świadczą dalekie od kompletności zasoby polskiego podręcznika (nie tylko zresztą do nauki historii) w księgozbiorach polskich bibliotek.

Bardzo nieliczne opracowania poświęcone zostały edytorskim aspektom podręczników szkolnych, a zatem problematyce interesującej autora niniejszego tekstu. I tak udało się odnaleźć niezwykle interesujący artykuł traktujący o próbach zastosowania grażdanki w polskich podręcznikach wydawanych na terenie zaboru rosyjskiego ${ }^{25}$, a także prace Marii Bieniek poświęcone kartografii w podręczniku, jak również kwestii ilustracji26.

\section{Prace poświęcone wydawcom i drukarniom podręczników}

Podobnie skąpo reprezentowane są opracowania omawiające miejsce podręcznika w działalności edytorskiej i poligraficznej XIX stulecia. Temat ten poruszany jest tylko marginalnie, a do wyjątków należą prace poświęcone lokalnym ośrodkom produkcji podręczników (Elbląg, Łódź, Poznań), a także wydawnictwom specjalizującym się w edycji podręczników ${ }^{27}$. Przyznać zatem trzeba, że tworzy

${ }^{23}$ W. Górczyński, Podręcznikowe zarysy dziejów Polski Henryka Schmitta, [w:] Wielokulturowe środowisko historyczne Lwowa w XIX i XX w., T. 2, s. 70-81; R. Ilnicka-Miduchowa, T. Słowikowski, Jeszcze w sprawie prospektu podręcznika do nauczania historii w opracowaniu lgnacego Potockiego, „Rocznik Naukowo-Dydaktyczny WSP w Krakowie” 1970, Z. 35, Prace Historyczne [nr] 5, s. 121-126; T. Słowikowski, Joachim Lelewel jako krytyk podręczników do nauczania historii, „Sprawozdania z Posiedzeń Komitetu Naukowego PAN. Oddział w Krakowie" 1972, T. 16, cz. 1 [druk. 1973], s. 77-78; tenże, Joachim Lelewel, krytyk i autor podręczników historii, Warszawa 1974; Z. Świątyńska, Zbeletryzowane podręczniki do nauki dziejów ojczystych Teresy Jadwigi Papi, „Prace Naukowe Uniwersytetu Śląskiego" 1975, Nr 89, Prace Dydaktyczne, z. 7, s. 67-76; M. Treszel, Echa Komisji Edukacji Narodowej w podręcznikach szkolnych Józefa Lompy, [w:] Echa Komisji Edukacji Narodowej na Śląsku, red. T. Musioł, Opole 1974.

${ }_{24}$ M. Bolechowska, Recepcja podręczników do nauczania historii, [Katowice 1965], s. 105-108.

${ }_{25}$ M. Strycharska-Brzezina, Polskojęzyczne podręczniki dla klasy I szkoły elementarnej w Królestwie Polskim drukowane grażdanką. Wydania warszawskie ze zbiorów Biblioteki Jagiellońskiej w Krakowie, rozprawa filologiczno-historyczna i edytorska, Kraków 2006.

${ }_{26}$ M. Bieniek, Kartografia historyczna w polskich podręcznikach historii (1795-1863), [w:] Historia. Społeczeństwo. Wychowanie, red. J. Maternicki, M. Hoszowska, P. Sierżęga, Rzeszów 2003, s. 124-136; M. Bieniek, Merytoryczne, dydaktyczne i techniczne aspekty ilustracji w polskich podręcznikach historii okresu 1864-1914, [w:] Historia. Poznanie i przekaz, red. B. Jakubowska, Rzeszów 2000.

${ }_{27}$ W. Chojnacki, Wydawnictwa polskie i ich drukarnie w Elblągu (w. XVII-XIX), „Rocznik Elbląski” 1966, T. 3, s. 105-117; J. Jaworska, Łódzkie wydawnictwa podręcznikowe (do 1918 r.). „Roczniki Biblioteczne" 1970, R. 14, z. 1-2, s. 329-350 [Od 1888 r.]; I. Lewandowska-Jaraczewska, Inicjatywy wydawnicze Zakładu Narodowego im. Ossolińskich w latach czterdziestych XIX wieku, „Ze Skarbca 
to ogromne możliwości pracy badawczej, odkrywczej zwłaszcza w odniesieniu do książki dziewiętnastowiecznej.

Tymczasem literatura bibliologiczna zawiera wiele informacji - choć rzadko wyodrębnionych - na temat produkcji podręczników, jako pewnego fragmentu repertuaru wydawniczego i drukarskiego. Trudno tu dokonać wyczerpującej analizy tej literatury, niech przykładem będzie tylko znakomite, należące dziś do klasyki literatury bibliologicznej, opracowanie dziejów wrocławskiej firmy Kornów - autorstwa Aleksandry Mendykowej - zawierające rozdział poświęcony polskim podręcznikom szkolnym oraz książce dla dzieci i młodzieży obecnym w repertuarze tej zasłużonej oficyny ${ }^{28}$. Tego typu literatura skupia się na bibliologicznych aspektach produkcji, dystrybucji i użytkowania książki i stanowi ważne uzupełnienie rozważań nad instytucją podręcznika, jego zawartością merytoryczną i dydaktyczną, prowadzonych przez historyków oświaty.

\section{Perspektywy badań}

Kreśląc perspektywy prac badawczych w omawianym przez artykuł zakresie, zacząć trzeba od podkreślenia konieczności stworzenia możliwie pełnej bibliografii podmiotowej. Rzecz dotyczy zwłaszcza edycji wieku XIX, najgorzej reprezentowanych w polskich zbiorach bibliotecznych, warto jednak rozszerzać owe prace na takąż literaturę okresu międzywojennego, także zachowaną w bibliotekach w stanie dalekim od kompletności. Podstawą opisu bibliograficznego winna być autopsja, w wielu przypadkach konieczna dla rozwikłania licznych rozbieżności występujących w katalogach bibliotecznych. W przypadku podręczników szkolnych do nauczania historii, wydawanych w latach 1795-1918 - prace takie są prowadzone ${ }^{29}$. Warto jednak zauważyć, że na takie zestawienia bibliograficzne oczekują także liczne podręczniki innych aniżeli historia przedmiotów.

Dopiero na tym materiale, wykorzystując liczne źródła i opracowania wchodzące w zakres bibliologii, ale także innych nauk humanistycznych (historii ogólnej i regionalnej, historii oświaty i wychowania, biografistyki), można budować zarysy monografii opisującej typologię podręcznika i jej przemiany, inicjatywy wydawnicze, krąg autorów, procesy produkcji wydawniczej i drukarskiej, instytucje działające na tych polach, proces dystrybucji, wreszcie recepcję książki szkolnej, by wymienić tylko główne obszary zainteresowań. Dopiero po uzyskaniu odpowiedzi na pytanie nie tylko o materialny kształt podręcznika, nasza wiedza o książce kształtującej przez ponad sto lat braku własnej państwowości młode pokolenie Polaków będzie prawdziwie pełna.

Kultury" 1979, Z. 32, s. 155-184; J. Wojtal, Ossolińskie wydawnictwo książek szkolnych w działalności Antoniego Małeckiego, „Rocznik Zakładu Narodowego im. Ossolińskich” 1974, T. 9, s. 107-116; J. Wojtal, Wydawnictwo Książek Szkolnych w Zakładzie Narodowym im. Ossolińskich 1878-1918, Wrocław 1976.

28 A. Mendykowa, Kornowie, Wrocław 1980.

${ }^{29}$ Badania te prowadzone są w Zakładzie Teorii i Historii Książki Instytutu Informacji Naukowej i Bibliotekoznawstwa Uniwersytetu Wrocławskiego. 